This PDF is a simplified version of the original article published in Internet Archaeology. Enlarged images, and interactive features which support this publication can be found in the original version online. All links also go to the online version.

\title{
A Tricky Subject - archaeology in opinion polls on cultural heritage. Recent examples from Poland
}

\section{Agnieszka Oniszczuk}

\section{Summary}

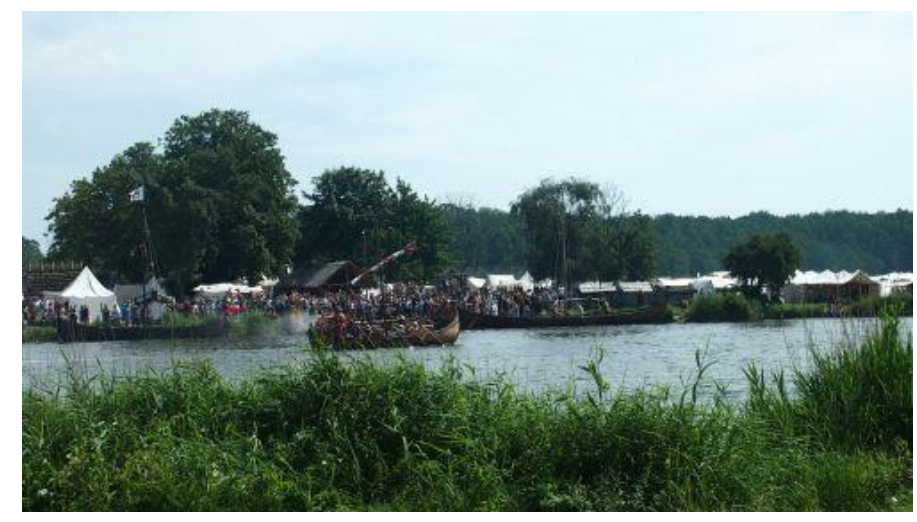

Visitors observing long boats arriving at the Slavs and Vikings' Centre Wolin - Jomsborg - Vineta in north-western Poland, July 2013, @ Agata Byszewska.

Understanding the public by analysing the wants, interests and expectations regarding their involvement in archaeology is one of the strategic aims of Europae Archaeologiae Consilium (EAC). Cultural heritage has been the topic of several public opinion polls in Poland over the past few years. In 2011 and 2015, the Narodowy Instytut Dziedzictwa (National Institute of Cultural Heritage) carried out two representative surveys. Subsequent polls focusing on more specific issues or groups of respondents were undertaken in 2015, 2017 and 2018. Other data from Poland come from the 2017 Special Eurobarometer survey on cultural heritage. They can be contrasted with archaeology-orientated opinion polls: a Europe-wide survey carried out within the NEARCH project led by Inrap (French National Institute for Preventive Archaeological Research) and several smaller-scale projects, which might be treated as starting points for more representative research.

The scope of these surveys includes: public perception of cultural heritage and archaeology, subjective value of cultural heritage, attitudes towards archaeology, relevance of archaeology for the present (also in terms of the socio-economic potential 
of archaeological heritage), people's interaction with archaeology and archaeological heritage, sources of information about archaeological heritage etc.

Comparison of these data will serve to establish the relevance of surveys for archaeological heritage management. The author will also examine if the specific nature of archaeological heritage is reflected in the surveys and how the public feels about its most hidden heritage. Based on the results of her analysis, the author will look at the desired scope of a survey aimed at filling the identified gaps and shaped to fit the needs of evidence-based archaeological heritage management.

\section{Introduction}

Cultural heritage, as described by the European Heritage Strategy for the 21st century, 'is a key factor for the refocusing of our societies on the basis of dialogue between cultures, respect for identities and diversity, and a feeling of belonging to a community of values'. It is also 'a powerful factor in social and economic development through the activities it generates and the policies which underpin it. (...) It constitutes an invaluable resource in the fields of education, employment, tourism and sustainable development' (Council of Europe 2017, 4). Considering its cross-sectorial impact, the evidence-based decisions in cultural heritage policy making are crucial. However, the slow realisation of this fact has been visible only since the end of the 20th century, along with the gradual acknowledgment of culture (and heritage) as a driver for development and one of the pillars of sustainable development (Giraud-Labalte et al. 2015, 50-1).

Data gathering on a European level started in 2001, when the first culture-related Eurobarometer survey was carried out (European Commission 2002). Six years later, Eurostat published its first cultural statistics pocketbook (Eurostat 2007). In the same year, the European Agenda for Culture put 'developing data, statistics and methodologies in the cultural sector and improving their comparability' among priority areas for action for the years 2008-2010 (European Union 2007, Annex). Recently, evidence-based policy making has been recognised as one of four main principles of European Framework for Action on Cultural Heritage. According to this document, Eurostat will keep improving the methodology and tools to collect data for cultural statistics, in cooperation with the statistical offices of EU Member States (European Union $\underline{2019}$, 9).

Within the EAC, the topic of data gathering in archaeological heritage management was addressed in the Amersfoort Agenda, its strategic document formulated in 2015. Members of the EAC acknowledged that in order to embed archaeology in society archaeologists should 'stimulate and facilitate society's involvement in archaeology'. They should 'monitor changing trends and then forge connections with other policy domains, such as education, economy, the environment and social challenges (...)'. In order to do this, they must know the public through the analysis of their wants, interests and expectations (Schut et al. 2015, 16). 


\section{Recent Cultural Heritage Opinion Polls in Poland}

Conveniently, over the past few years, cultural heritage has been the topic of several representative public opinion polls in Poland. In 2011, the National Institute of Cultural Heritage carried out the first pilot survey on the value of cultural heritage to society (Kozioł et al. 2013). Next, a more comprehensive one took place in 2015 (Chabiera et al. 2017). Other representative data from Poland were gathered during the Special Eurobarometer survey on cultural heritage, carried out in 2017 during preparations for the European Year of Cultural Heritage (European Commission 2017).

The scope of these polls corresponds with themes taken up by the EAC within the 'Making Choices' initiative, such as the perception of cultural heritage and monuments, their role and importance, the subjective value of cultural heritage, attitudes towards heritage, its relevance to the present in terms of the socio-economic potential, people's interactions with monuments and heritage, preferred sources of information etc.

More specific surveys, focusing on local communities, were carried out by the $\mathrm{NICH}$ in 2017 and 2018 and their results are currently being summarised for publication. The former analysed the views of representatives of the so-called Local Action Groups, i.e. private-public partnerships, formalised or not, supporting their respective areas through the implementation of various small-scale projects. In the latter the researchers turned to local leaders, namely village heads or mayors and heads of commune culture centres. Questions in both polls focused on the roles and potential of cultural heritage, management, local actions and policies.

The above can be juxtaposed with archaeology-orientated opinion polls. A Europeanscale survey carried out in 9 countries as part of the NEARCH project led by Inrap (French National Institute for Preventive Archaeological Research) has delivered plenty of interesting data on public perceptions of archaeology and attitudes towards this science in Poland (Richards et al. 2017; Martelli-Banégas et al. 2015a; 2015b).

Important issues of public participation have also been highlighted by two smaller projects. One entitled Social Engagement in Archaeology (Zaangażowanie społeczności lokalnej w ochronę dziedzictwa archeologicznego w Polsce) was carried out in 2015 by a team of researchers led by Dr Małgorzata Kot from the University of Warsaw (Kot et al. 2015). It focused on several archaeological heritage-related groups of respondents: archaeologists (138 people), re-enactors (17 people), visitors to archaeological festivals (143 people) and local communities in villages with excavations ongoing nearby (53 people). Questions tackled the issues of responsibility for archaeological heritage, its appeal and potential, personal interests and involvement etc. Archaeological expectations of one local community were studied in the project entitled 'Involved Archaeology: society - past - remote sensing', a joint initiative of archaeologists and students from the Institute of Archaeology of Adam Mickiewicz University in Poznan and the local association for rural development (Razem) from the village of Bieniów in western Poland (Lubuskie Voivodeship), inspired by the latter (Kostyrko et al. 2016, 86). The project, carried out in 2013, included non-intrusive research on an early medieval 
hillfort, a study of the attitudes of the local community towards archaeology and dissemination activities.

\section{Generally Fine}

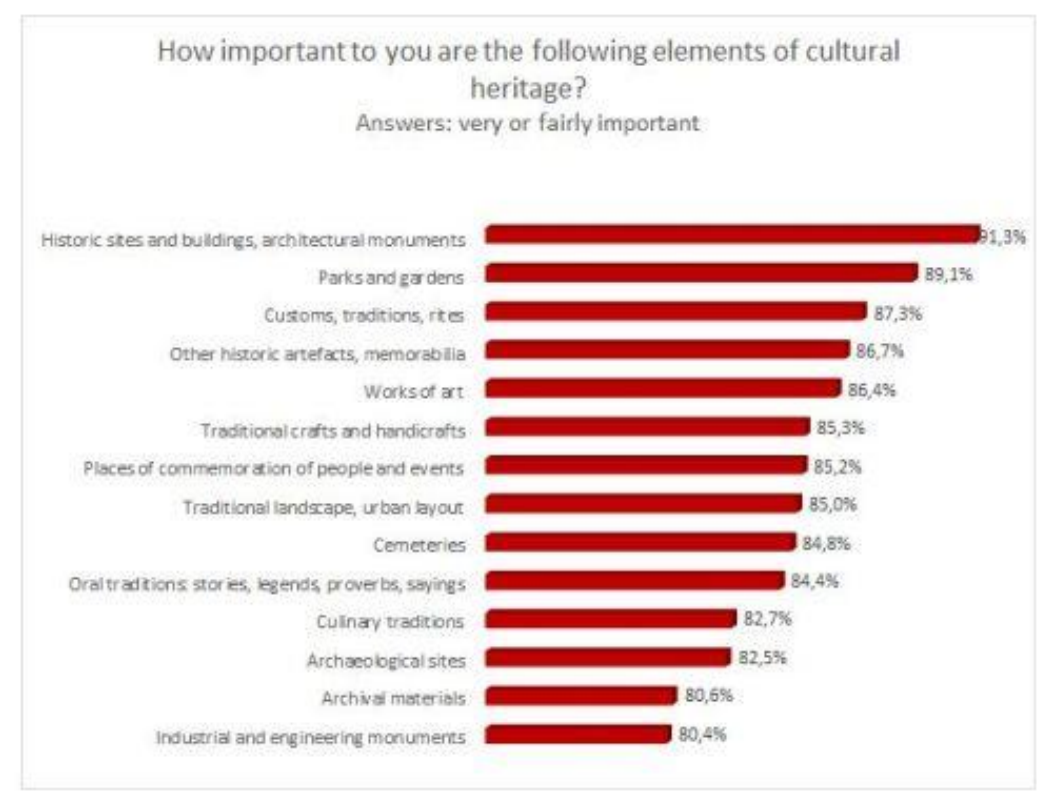

Figure 1: One of the questions from a representative survey carried out by the National Institute of Cultural Heritage in 2015. Source: Fortuna-Marek and Stępnik 2017, 34.

On a European level, the most fundamental observations of the Eurobarometer survey of 2017 were very optimistic. The vast majority of Europeans considered cultural heritage important to them personally (84\% of Europeans and Poles responded 'very important' and 'fairly important') and to their countries (91\% of Europeans, $89 \%$ of Poles responded 'very important' and 'fairly important) (European Commission 2017, 21-4). Similarly high results were also obtained two years earlier in the $\mathrm{NICH}$ survey, with respective answers of $86 \%$ and $85 \%$. Furthermore, cultural heritage was more often considered important by the older and better educated respondents, which means that its valuation and a positive emotional attitude towards it seem to be the offshoots of knowledge and experience (Fortuna-Marek and Stępnik 2017, 24-7).

Appreciation of cultural heritage was also observed when the respondents were asked about the importance of individual categories (Figure 1): all of them scored $80 \%$ or over. However, scrutiny of these results reaches the core of the problem raised in this article, namely the subjective perception of archaeological heritage and its valuation.

Alarmingly, $82.5 \%$ of respondents valued archaeological sites 12th out of a possible 14 . Only archives and technical monuments were less valued (Fortuna-Marek and Stępnik 2017, 33-5), and these are the categories that are sometimes not perceived as monuments at all. 


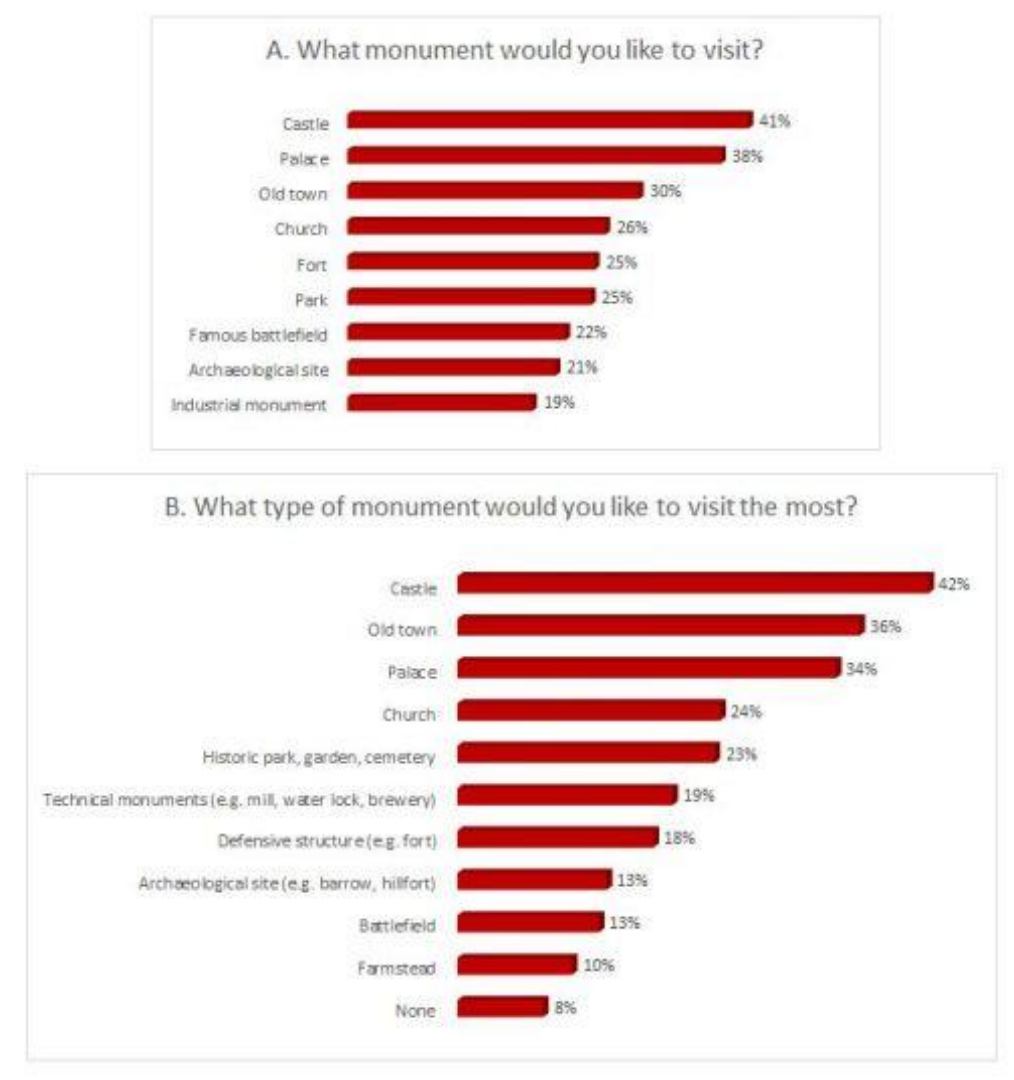

Figure 2: Questions asked in representative surveys carried out by the National Institute of Cultural Heritage (A) in 2011. Source: (A) Kozioł et al. 2013, 73; In 2015 (B) Dąbrowski and Kozioł 2017, 53.

In this context, it is not surprising that archaeological sites, coming in 8th place in the surveys of 2011 and 2015, were not a magnet attracting potential visitors (Figure 2). To underline the gravity of the situation, in the survey of 2015 on places to visit (Figure 2B) almost 30 percentage points separated archaeological sites from castles, the most popular category, and only 5 from 'none'. In addition, in 2011 when respondents were asked about the three most important monuments in Poland, of the 268 monuments indicated only one archaeological site (a Bronze Age settlement in Biskupin, now partially reconstructed and functioning as an open-air museum with $4.5 \%$ of selections) and one archaeological museum (Rynek Underground, Branch of the Museum of Krakow) (NICH 2011, unpublished results of the survey) were ranked. Such a low potential of archaeological heritage seems to give heritage managers every reason to despair; however, closer analysis of what the above survey questions implied may offer a beacon of hope for the future.

\section{The Pitfalls of Categorisation}

In the Special Eurobarometer poll on cultural heritage, palaces, castles, archaeological sites, gardens etc. have been included in one category of historical monuments or sites (European Commission 2017, 48-9). In contrast, authors of the general opinion polls, carried out for the National Institute of Cultural Heritage in 2011 and 2015, subdivided the heritage in order to obtain more detailed results. However, in the case of archaeology, that solution became the main problem. 
In both surveys the respondents had to choose between archaeological sites and castles, old towns, churches, forts, historical parks and gardens etc. Such a choice is false by definition, as it ignores the modern understanding of archaeology and the everexpanding chronological scope of its interests. The essence of the archaeological monument is not a simple derivative of a function, but of location (below ground, underwater), chronology (relics of the past) and, at least partly, of the state of preservation (unused objects).

Archaeological sites cannot be separated from other remains of the past, just like they cannot be extracted from the cultural landscape. Subsequent phases of construction and use of architectural monuments, ruined or not, or historical parks and gardens are reflected in archaeological contexts buried below the ground. Cemeteries from the modern and contemporary (1800 onwards) periods are studied by archaeologists just like prehistoric burial grounds. Thanks to archaeological data, chronology known through historical sources can be clarified and even the distribution of archaeological objects can provide information on past events such as military actions (Wrzosek 2017, 84).

To rephrase the survey questions in the above context, the respondents had to choose between various categories of archaeological monuments, and the one of archaeological sites (exemplified in 2015 by barrows and hillforts), which encompassed sites located outside of urban areas, with no architectural relics visible on the surface and dated to prehistory or, in the case of Poland, mostly early middle ages. A similar approach to categorisation was demonstrated in the study of about 80 Local Action Groups from 2017 (Figure 3). Needless to say, the distribution of answers resembled the questions discussed above.

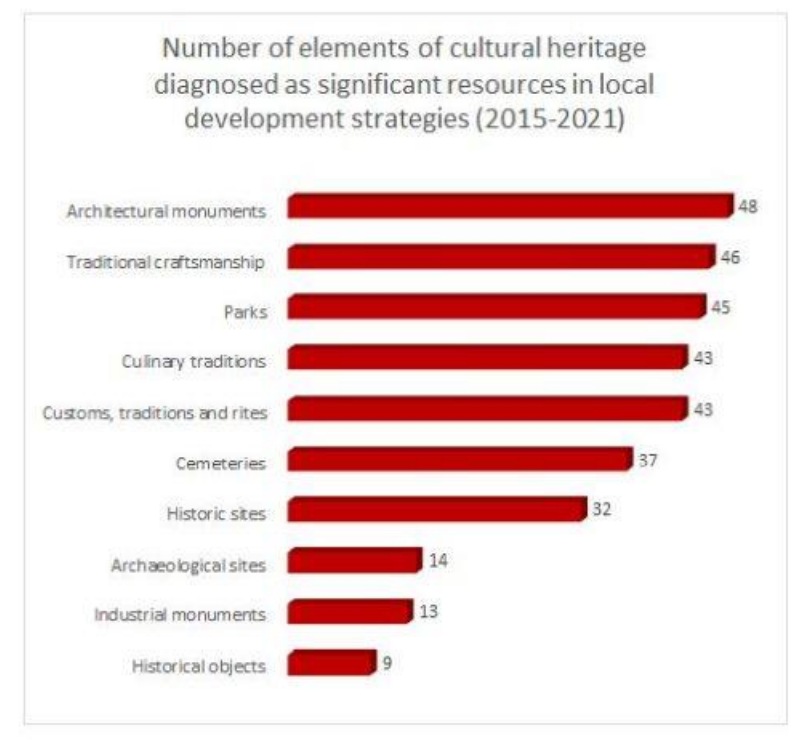

Figure 3: Data from unpublished survey of Local Action Groups carried out for the National Institute of Cultural Heritage in 2017.

\section{The Roles of Cultural Heritage}

Archaeologists communicating with the wider world, be it schoolchildren, students, developers, landowners or various authorities, realise that the meaning and potential of 
archaeological heritage can be difficult to understand for non-professionals. Results of heritage public opinion surveys confirm this observation.

Generally, people appreciate cultural heritage. In 2011 almost $90 \%$ of the respondents said that it had an important social role in the society (Kozioł et al. $\underline{2013}$, 29). Then, and in 2015 , they thought that monuments improved the quality of life, and monuments were understood as something more than their purely material aspect. Their value lay in the fact that they were seen as a testament of history and a source of knowledge. They made the place of residence unique and gave communities a feeling of local pride. Increasing the aesthetics of place, they were places of recreation and rest (FortunaMarek and Stępnik 2017, 28-33; Kozioł et al. 2013, 30). Additionally, in the 2018 survey of local leaders, in the question about the potential that could be used for economic development, local monuments with a score of $95.4 \%$ outranked intangible cultural heritage by over 40 percentage points ( $\mathrm{NICH}$, unpublished survey).

Such results are impressive; however, the weak position of the archaeological sites category presented above indirectly indicates that they probably do not apply to archaeological heritage. These concerns have been directly confirmed by the NEARCH project. Only $8 \%$ of Polish respondents thought that archaeology could contribute to the quality of life. On the other hand, the main roles attributed to archaeology by Poles, namely knowing the history of Poland (57\%), participating in the study and protection of cultural heritage (47\%), passing history down to younger generations (44\%), understanding the past to better prepare for the future (40\%) and understanding our own place in the world through our shared past (30\%), seem quite sophisticated and nonrelatable to everyday life. What is also interesting, against firm beliefs of archaeological heritage managers, the functions of identity building, uniting and entertainment received much lower support (Martelli-Banégas et al. 2015b, Q4).

\section{The Economic Potential}

The overall economic potential of cultural heritage and, more specifically, the monuments has been acknowledged in Poland and Europe. In $201186 \%$ of Poles thought that you 'could make money on a monument' (Kozioł et al. 2013, 84). Over a half agreed that monuments improved tourism and could bring income to local communities (Kozioł et al. 2013, 34). Four years later, 73.5\% of the respondents in Poland still considered cultural heritage a source of income, workplaces, products and services as well as commercial activities in local communities (Chabiera et al. 2017, 89-90).

In 2017 almost 8 out of 10 Europeans stated that cultural heritage and related activities created jobs in the EU (European Commission 2017, 62). The awareness of the latter was greater among those who came into contact with heritage on a daily basis owing where they lived, personal involvement or interests (European Commission 2017, 66).

According to the most recent study of local leaders, cultural heritage was already included in strategic documents and used in tourism (93\%), culture (76\%), education $(70 \%)$, agriculture and crafts $(43 \%)$, real estate and construction $(36 \%)$, and to a lesser extent in creative industries (22\%) ( $\mathrm{NICH} 2018$, unpublished survey).

As soon as similar questions are asked exclusively with regard to archaeological sites, the results are again not optimistic. In $2018,9 \%$ of the representatives of Local Action Groups believed that there was absolutely no chance that the sites could contribute to 
the local development, and this was the highest percentage of responses to this question among all the heritage categories. Linked to this, only $10 \%$ thought that archaeological heritage could have economic value. Over one-quarter of those interviewed found this question difficult to answer (unpublished survey of the NICH), and this also was the highest result for this response.

\section{Responsibility for the Difficult Heritage}

Comparison of answers regarding cultural heritage, and specifically its archaeological aspects, indicate that the general public find it difficult. Archaeological sites are not the monuments they think of and relate to in everyday life. On the contrary, they seem distant and their potential is seen as quite abstract, which is reflected also in the feeling of responsibility for archaeological heritage.

Polish people thought that heritage should be preserved unconditionally (65\%) or if it could be, adapted to new functions (25.6\%) (Fortuna-Marek and Stępnik 2017, 38-9). This view was confirmed by almost all local leaders surveyed in 2018 (98\%, unpublished survey of the $\mathrm{NICH}$ ). Moreover, cultural heritage preservation was worth public spending (82\% in 2011 and 86\% four years later) (Kozioł et al. 2013, 63; Chabiera et al. 2017, 94). Therefore, the government and governmental organisations and, particularly according to the representatives of communal self-government, various levels of local authorities, should be mainly responsible for the heritage (Dąbrowski and Kozioł 2017, 71-2; NICH 2018, unpublished survey). The $2015 \mathrm{NICH}$ survey also showed that the awareness of civic responsibility in this regard increased with education (Dąbrowski and Kozioł 2017, 71-2).

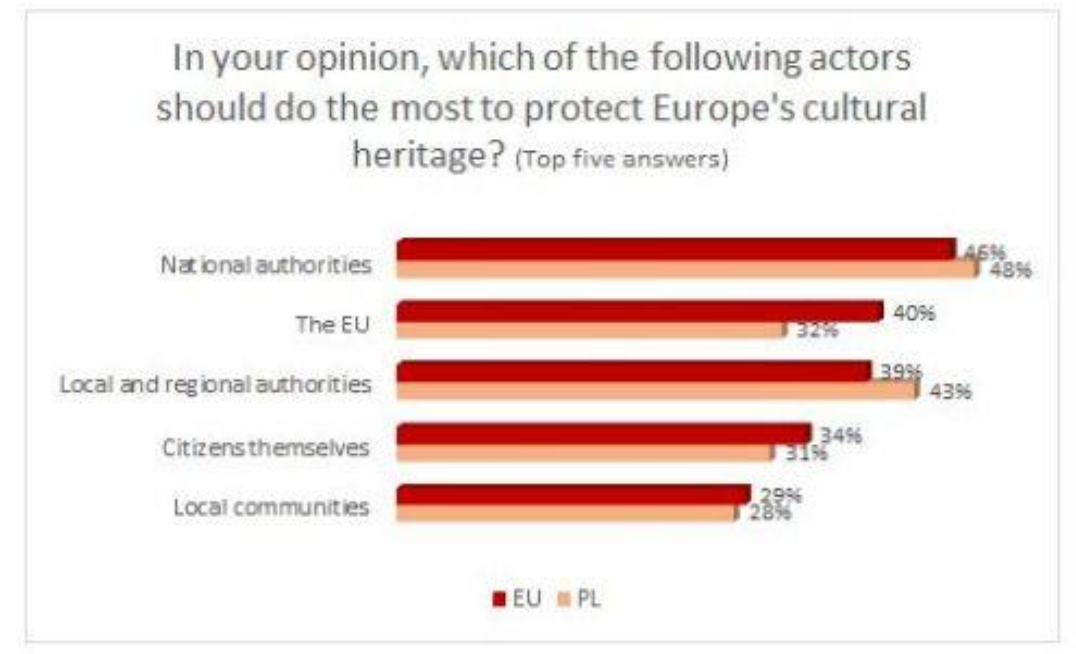

Figure 4: One of the questions from a Special Eurobarometer survey on cultural heritage from 2017. Source: Specjalny Eurobarometer 466. Polska, 4, QB11

On a European level, national governments, the EU and local authorities should do the most for heritage protection and, subsequently, it should be the citizens and local communities (Figure 4) (European Commission 2017, 75; Komisja Europejska 2017, 4, QB11). The latter two combined would have come first in the EU survey with $63 \%$ of 
responses. Polish respondents have given more responsibility to government and local authorities and less to the EU. They also were among the least likely to mention the citizens (European Commission 2017, 75).

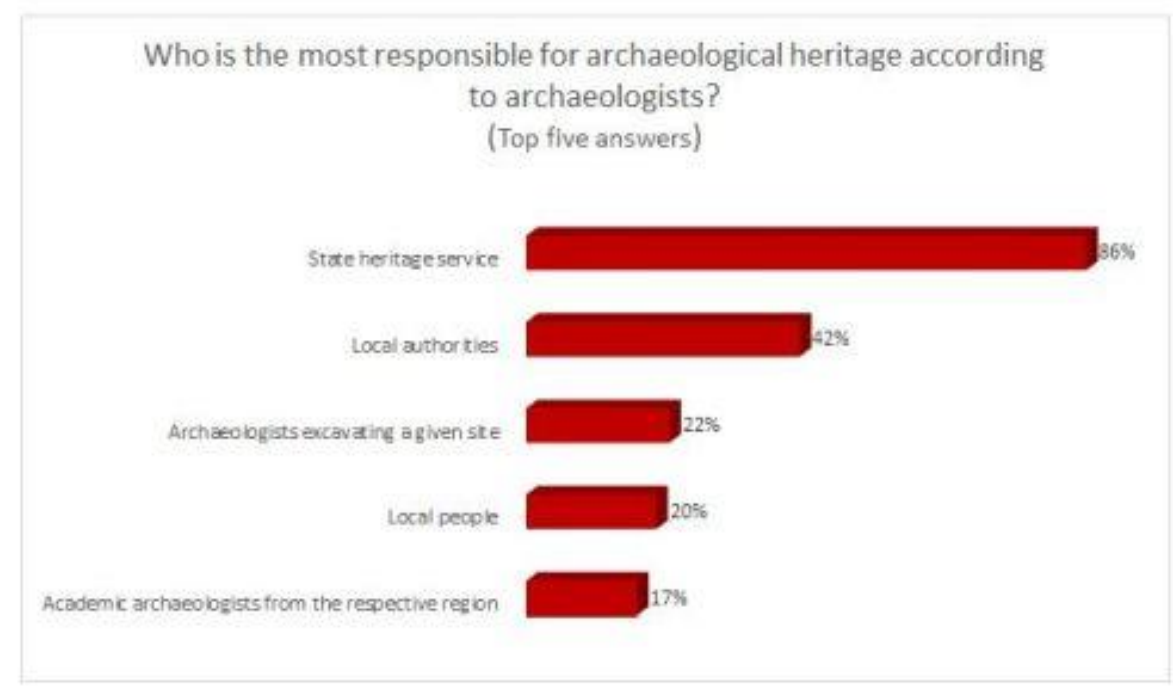

Figure 5: Data from un unpublished report from a project entitled Social Engagement in Archaeology ('Zaangażowanie społeczności lokalnej w ochronę dziedzictwa archeologicznego w Polsce') carried out in 2015 by a team of researchers led by Dr Małgorzata Kot from the University of Warsaw (Kot et al. 2015). Based on: Jędrzejczak and Mieszczanek 2015, 217-18. Summed responses 1-3 in a 9-point scale.

Similar questions have been asked in archaeology-related surveys. Unsurprisingly, the answers were quite different. Almost three-quarters of Polish respondents in the NEARCH survey agreed that it was the State's job to manage archaeology (MartelliBanégas et al. 2015b, Q18). Visitors to archaeological festivals, interviewed within the Social Engagement in Archaeology project, have placed the greatest responsibility for heritage protection on state heritage service (32\%), citizens $(27 \%)$, authorities at various levels (25\%) and archaeologists (16\%). Archaeologists have had much more faith in professionals and officials than local people, with $86 \%$ pointing at state heritage service and $42 \%$ at local authorities (Figure 5). At the same time, they recognised their professional responsibility (39\%), which for them was almost double the responsibility of local inhabitants (20\%) (Jędrzejczak and Mieszczanek 2015, 217-18).

Notwithstanding a certain sense of social responsibility for archaeological and more general cultural heritage, the results of all studies indicate that it should remain at the discretion of authorities and state institutions.

\section{Who is Going to Care?}

In the 12 months preceding the Eurobarometer heritage survey, $61 \%$ of respondents had visited a historical monument or site (e.g. palaces, castles, churches, archaeological sites, gardens) at least once; in Poland it was less than a half (European Commission 2017, 48-50; Komisja Europejska 2017, 2, QB4). In this particular instance, however, this is not the point. More significant findings came from the sociodemographic analysis of the answers regarding visiting heritage places and events. The 
list of activities included going to a library or archive (to consult original sources), a historical monument or site, a museum or gallery, a traditional event (e.g. carnival), a traditional crafts workshop, a traditional or classical performing arts event (e.g. opera or folk music) as well as seeing classic European films produced at least 10 years before the survey.

The Eurobarometer has confirmed on a European level a tendency that was visible in the 2015 survey of the NICH (see Section 3). The longer the time spent in education, the more likely the participation in heritage activities, with $78 \%$ of respondents who completed their education aged 20 or after having visited a historical monument or site, compared to $34 \%$ whose education finished aged 15 or younger. Additionally, the Europeans who lived close to any form of cultural heritage, those who were personally involved in cultural heritage and, not surprisingly, those who were interested in knowing more about Europe's cultural heritage, were more likely to have done each of those heritage-related activities. For instance, $72 \%$ of people interested in cultural heritage have visited a historical monument or site, compared to $37 \%$ of the uninterested (European Commission 2017, 55).

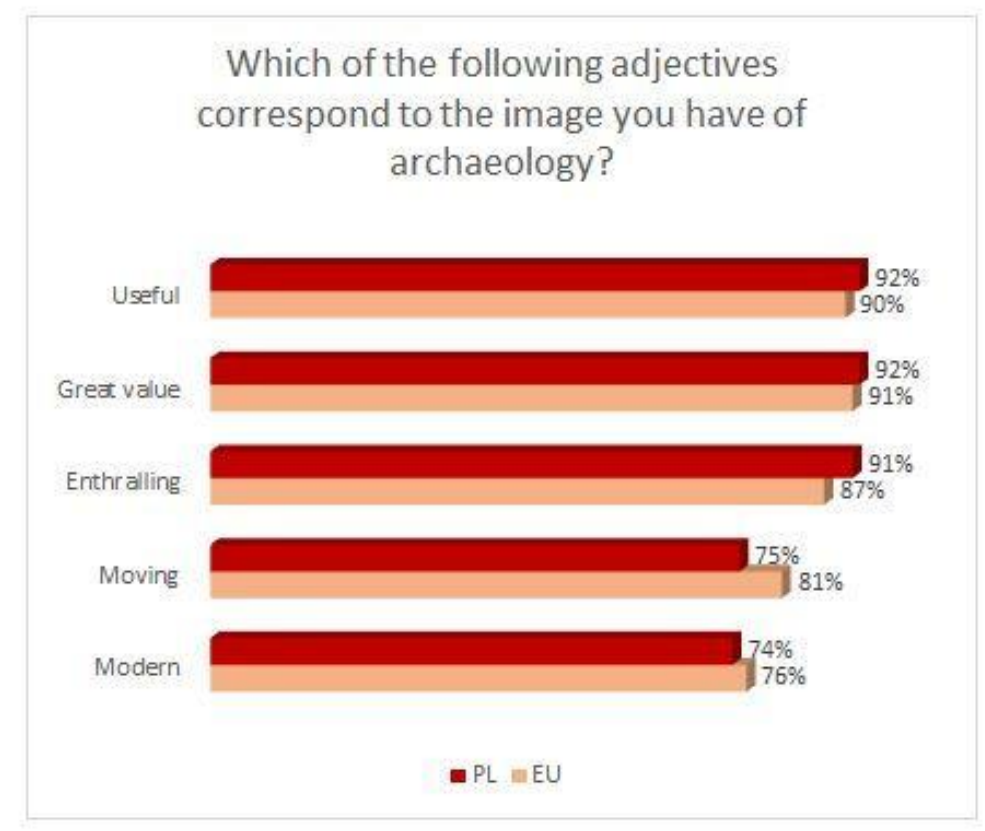

Figure 6: Selected of answers to a questions asked in the survey carried out in 2015 within the NEARCH project. Source: Martelli-Banégas et al. 2015b, Q13.

Since we already know that the increase in knowledge about heritage goes hand in hand with a better understanding of its value, it is the fact that the archaeological heritage is relatively unknown that gives some hope for the future. The more so because the $\mathrm{NEARCH}$ project survey has shown that we have enormous wealth at our disposal; $27 \%$ of Europeans and $25 \%$ of Poles once wanted to study archaeology (Martelli-Banégas et al. 2015b, Q9), which means that they may still have retained some sentimental attachment to this discipline. Their image of archaeology seems to confirm this (Figure 6): $92 \%$ of Poles considered it useful and of great value, for $91 \%$ it has been enthralling and for over three-quarters it was seen as moving; European results have been only a few percentage points lower (Martelli-Banégas et al. 2015b, Q13). One out of ten has also believed that the existence of archaeological relics is an advantage to a given location (Martelli-Banégas et al. 2015b, Q14). Furthermore, the NICH survey has 
demonstrated that people visit monuments for personal reasons, out of interest, the will to gain new knowledge, or to share their passion with family and friends (Dąbrowski and Kozioł 2017, 47-8). Thus, regardless of the difficulties arising from the specificity of archaeological heritage, it still has positive connotations, a potential that seems the easiest to exploit in tourism and leisure-related educational activities.

\section{The Power of Attraction(s)}

In the light of the NEARCH survey there is a lot be done in Poland. On the one hand, the respondents have considered archaeological exhibitions in Polish museums informative for every age group, on the other too little attention has been geared towards Polish archaeological history. People also thought that there was too little knowledge dissemination about archaeological research and finds aimed at the Polish public and too little information on what they could see and do with regard to archaeology (MartelliBanégas et al. 2015b, Q15).

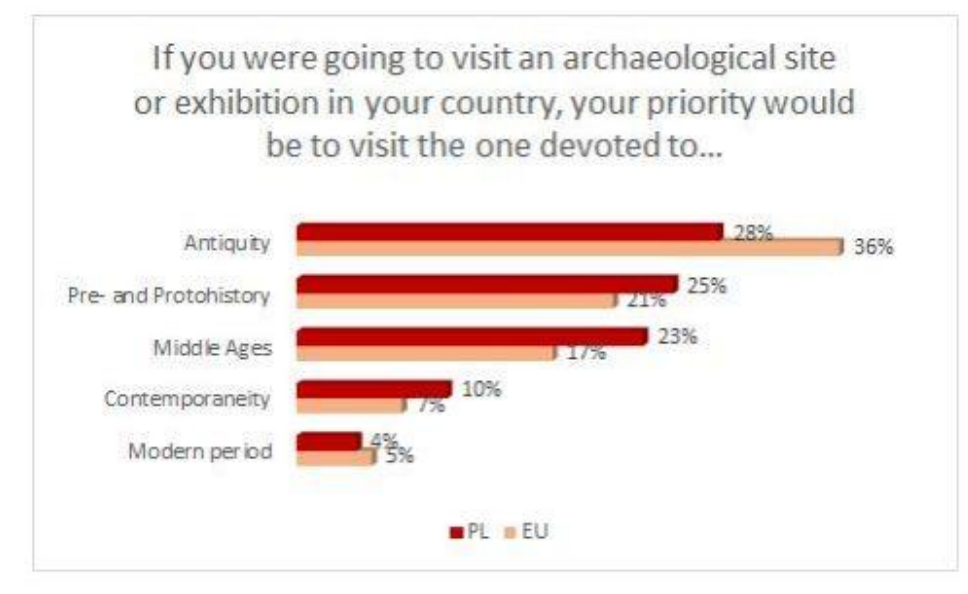

Figure 7: One of the questions from the survey carried out in 2015 within the NEARCH project. Based on: Martelli-Banégas et al. 2015b, Q11.

The first choice of respondents considering a visit to an archaeological exhibition or site would have been the ones devoted to ancient Greece or the Roman Empire as well as prehistory and protohistory (Figure 7). Slightly fewer than a quarter would have been interested in places and events related to the middle ages and Polish ruling dynasties. Much fewer respondents have chosen the two world wars, the interwar decades or the modern period. Comparison with results from other countries and the European average shows that great interest in the history of their own country, especially periods highlighted in school education, is a characteristic feature of Poles (Martelli-Banégas et al. 2015b, Q11).

As for accompanying tourist attractions offered at monuments, in 2011 the Polish people chose exhibitions, concerts, festivals, sound-and-light shows and restaurants (Figure 8) (Kozioł et al. 2013, 81). Four years later guided tours, open-air events, workshops and lessons on local history, souvenir shops, visitor centres and active forms of sightseeing were added to the list (Dąbrowski and Kozioł 2017, 55). Quite surprisingly, mobile apps received only $6 \%$. They were unwanted, whereas archaeologists have been expressing the need for and the advantages of digital technologies in archaeological heritage promotion. This situation may change with a changing demographic and the spread of 
online heritage activities but this definitely is an issue that needs investigating, because, according to the Eurobarometer survey, the Europeans who use the Internet daily are much more likely to participate in heritage-related activities (European

Commission 2017, 55).

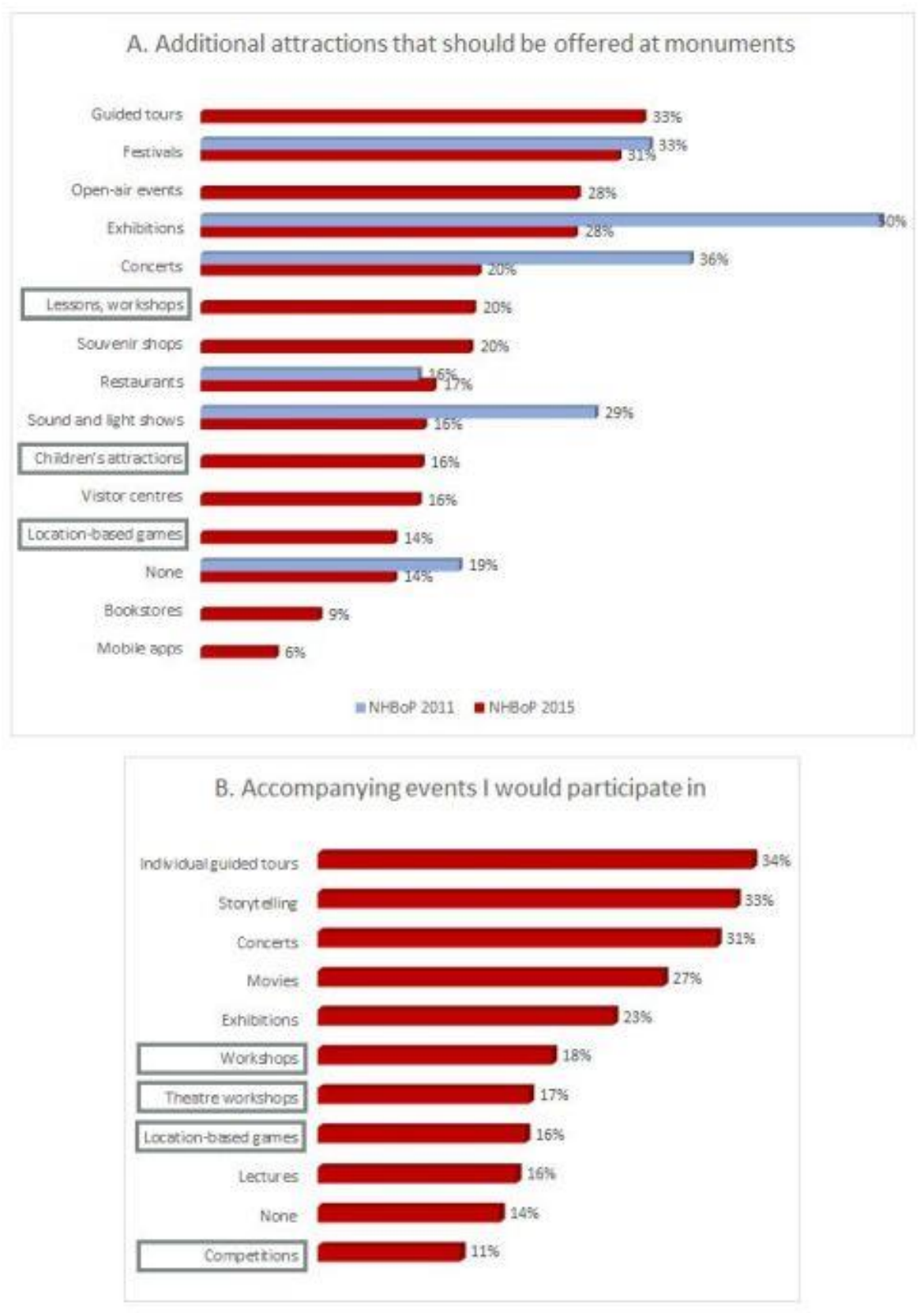

Figure 8: Data from representative surveys carried out by the National Institute of Cultural Heritage (formerly the NHBoP) (A) in 2011 and 2015 (B). Source: (A) Dąbrowski and Kozioł 2017, 55; Kozioł et al. 2013, 81; (B) Dąbrowski and Kozioł 2017, 57. Purely participatory activities are marked with a frame.

In the context of tourist attractions, an interesting observation from the project of Social Engagement in Archaeology should be noted. Visitors to archaeological festivals have rated all the attractions highly, but the highest number of negative ratings went to various participatory activities (Jędrzejczak and Mieszczanek 2015, 147). Similar 
reservations were observed among members of local communities interviewed within the project (Jędrzejczak and Mieszczanek 2015, 162). This tendency has been indirectly confirmed by the representative surveys of the $\mathrm{NICH}$ (Figure 8). Purely participatory activities, such as workshops, location-based games and competitions, were less popular (11.2-18.4\%, compared to over 20 or $30 \%$ for the most popular attractions) (Dąbrowski and Kozioł 2017, 57).

Exemplary views on the expectations of one local community were collected in 2013 within the smallest of the analysis projects: 'Applied archaeology: Society - past remote sensing'. Questionnaires were distributed in the villages of Bieniów and Biedrzychowice Dolne in western Poland, before a non-intrusive survey began and 54 questionnaires were completed. The respondents expected cooperation between archaeologists and society. They argued that archaeology enabled them to learn about the past of the area they lived in and was more interesting because it had not been part of school education (this last opinion appeared in the in-depth interviews carried out with 20 persons). Two respondents said that thanks to such interactions, people would understand and respect heritage, and one said that archaeologists, often financed with public money, owe information about research to the public. For most of the respondents the preferred forms of future interactions were meetings at the research site or other places and conversations describing the research and their results. Some wanted to visit archaeologists during work and significantly fewer wished to join the fieldwork, confirming the views on participation (Kajda and Kostyrko 2016, 17).

This passivity of the public was also noted by representatives of local authorities and cultural heritage NGOs, surveyed at the request of the NICH in 2015 by the Klon-Jawor Association. Some $70 \%$ of organisations and $67 \%$ of local authorities' representatives considered the involvement of local communities low. Almost as many thought that the level of awareness of cultural heritage in the local community was insufficient, and actions aimed at raising it were considered one of the most difficult tasks regarding cultural heritage (Adamiak and Charycka 2015, 13, 42, 62, 122). The discrepancy between the expectations of the community and the NGOs is worth emphasising, because the latter found the participatory activities more interesting (Adamiak and Charycka 2015, 44).

\section{Benefits of Surveys and the Way Forward}

Sustainable, systemic approach to exploiting the socio-economic potential of archaeological heritage has to be evidence based; however, its multifaceted nature makes the comprehensive study of all the aspects and issues very difficult.

Studies of cultural heritage as a whole proved not to be helpful in archaeological heritage management owing to the high level of generality. They are appropriate to infer some phenomena on a European scale, but the lower the level of heritage management, the less useful they become.

Categorisation observed in the representative surveys from Poland (Kozioł et al. 2013; Chabiera et al. 2017) was to be a means of overcoming the above issue. Seemingly, it delivered meaningful data, but closer scrutiny revealed that they cannot really be used 
as evidence in archaeological heritage management. The divisions used in the questionnaires have ignored the modern definition of archaeology and the broad scope of its interests. As a result, the data on archaeological heritage have been dispersed among categories, while those regarding archaeological sites de facto refer only to prehistoric and medieval extra-urban sites.

The above is a result of the lack of well-founded knowledge on archaeology. The NEARCH project has shown that people in Poland and Europe generally understand what archaeology is. They have thought that it is: a discovery, digging/excavation of objects, artefacts, relics, remains, human bodies, etc. $(61 \%, 37 \%$ in the EU); study and analysis of the past $(56 \%, 48 \%$ in the EU); study of old civilisations, human evolution, etc. (31\%), and study of ancient ruins, sites, dwellings, structures (13\%, $11 \%$ in the EU) (Martelli-Banégas et al. 2015b, Q1, top 4 answers). On the other hand, if people have not been taught the basic concepts and methods of modern archaeology at school, they have no grounds to question the common but dated understanding that is transmitted by the media. They do not discuss divisions presented in opinion polls but try to fit in.

The flawed data also revealed several warning signs showing that archaeological heritage is treated differently. It is distant and difficult. Archaeological relics are not as interesting or valuable to the people as architectural heritage or parks and gardens. The confirmation came from the comparison of cultural heritage and the archaeology-specific surveys, showing lesser understanding of the archaeological heritage potential, and on a more universal level, the benefits of evaluating the general data against the archaeological heritage ones.

Regardless of the reservations expressed above, the surveys we already have at our disposal are important because they allow the testing of expectations and ideas of heritage managers with sometimes surprising results. Examples include the issues of the low demand for mobile apps and the people's preference for passive reception of knowledge instead of active participation (see Section 9). However, the best basis for the evidence-based heritage management would be the data obtained from opinion polls devoted solely to archaeological heritage. They would have to tackle all the issues from the people's knowledge on archaeology to the socio-economic potential and its use. A representative survey of this kind, using also the results of this analysis, was carried out for the $\mathrm{NICH}$ at the end of 2020. Results are yet to be analysed.

I am also positive that heritage managers should focus on those non-professionals who are already interested in archaeology, because, according to the much-quoted statement by the global consulting Bain \& Company, acquiring a new customer is seven times more expensive that keeping the old one. Opinion polls should therefore be targeted at the organisers and participants of various outreach activities, archaeological heritage NGOs, museum visitors etc. The smaller projects I referred to above may serve as a starting point (Kot et al. 2015; Kajda and Kostyrko 2016). We should locate our client group, including the quarter that once wanted to be archaeologists (see Section 8 ) because the emotional appeal is a base that other disciplines do not have.

With the help of sociologists, we should decide whether to concentrate on expressed expectations or if we should rather create new needs, especially with regard to digital technologies and participation. The use of marketing theories (e.g. relationship-based marketing) and tools will allow us to retain and expand the interest in archaeology. It will also get the interested part of the general public to help us advocate for archaeological 
heritage. Only by taking on board the results of such research will it be possible to exploit the potential of this heritage to the fullest.

\section{Bibliography}

Adamiak, P. and Charycka, B. 2015 Działania organizacji pozarządowych oraz samorządów w obszarze dziedzictwa kulturowego: współpraca, potrzeby, zaangażowanie wolontariuszy, Raport z badania, unpublished report, Warszawa: Stowarzyszenie Klon/Jawor.

Chabiera, A., Dąbrowski, A., Fortuna-Marek, A., Kozioł, A., Nowak, P., Skaldawski, B. and Stępnik, K. 2017 Polacy wobec dziedzictwa. Raport z badań społecznych, Dziedzictwo kulturowe w badaniach, Warszawa - Kraków: Narodowy Instytut Dziedzictwa.

Council of Europe 2017 Recommendation of the Committee of Ministers to member States on the European Cultural Heritage Strategy for the 21st century (Adopted by the Committee of Ministers on 22 February 2017 at the 1278th meeting of the Ministers' Deputies), CM/Rec (2017) 1. https://rm.coe.int/16806f6a03

Dąbrowski, A. and Kozioł, A. 2017 'Zainteresowanie Polaków dziedzictwem kulturowym i zaangażowanie w działania z nim związane' in A. Chabiera, A. Dąbrowski, A FortunaMarek, A. Kozioł, P. Nowak, B. Skaldawski and K. Stępnik, Polacy wobec dziedzictwa. Raport z badań społecznych, Dziedzictwo kulturowe w badaniach, Warszawa - Kraków: Narodowy Instytut Dziedzictwa, 45-86.

European Commission 2002 Special Eurobarometer 158. Europeans' participation in cultural

activities. https://ec.europa.eu/commfrontoffice/publicopinion/index.cfm/Survey/getSurve yDetail/instruments/SPECIAL/surveyKy/213/p/7

European Commission 2017 Special Eurobarometer 466, Report. Cultural Heritage. https://ec.europa.eu/commfrontoffice/publicopinion/index.cfm/Survey/getSurve yDetail/instruments/SPECIAL/surveyKy/2150

European Commission 2018 A New European Agenda for Culture. Communication from the Commission to the European Parliament, the European Council, the Council, the European Economic and Social Committee and the Committee of the Regions. COM (2018) 267 final.

European Union 2007 Resolution of the Council of 16 November 2007 on a European Agenda for Culture. 2007/C 287/01. https://eur-lex.europa.eu/legalcontent/EN/TXT/?uri=CELEX:32007G1129(01)

European Union 2019 European Framework for Action on Cultural Heritage.

Commission Staff Working Document, Luxembourg: Publications Office of the European Union. https://op.europa.eu/en/publication-detail/-/publication/5a9c3144-80f1-11e9-9f0501aa75ed71a1 
Eurostat 2007 Cultural Statistics, Eurostat Pocketbooks, Luxembourg: Office for Official Publications of the European Communities.

Fortuna-Marek A. and Stępnik K. 2017 'Komponenty postaw Polaków wobec dziedzictwa kulturowego', in A. Chabiera, A. Dąbrowski, A. Fortuna-Marek, A. Kozioł, P. Nowak, B. Skaldawski and K. Stępnik Polacy wobec dziedzictwa. Raport z badań społecznych, Dziedzictwo kulturowe w badaniach, Warszawa - Kraków: Narodowy Instytut Dziedzictwa, 22-44.

Giraud-Labalte, C., Pugh K., Quaedvlieg-Mihailović, S., Sanetra-Szeliga ,J., Smith, B., Vandesande, A. and Thys, C. (eds) 2015 Cultural Heritage Counts for Europe. Full report, Krakow: International Cultural Centre.

Jędrzejczak, H. and Mieszczanek, M. 2015 'Raport z badań socjologicznych zrealizowanych w ramach projektu "Social Engagement in Archaeology. Zaangażowanie społeczności lokalnych w ochronę dziedzictwa archeologicznego"' in M. Kot, K. Pavlenok, H. Jędrzejczak, M. Mieszczanek, M. Sadłowski, J. Adamski, P. Danyło, D. Skolimowski, S. Shnayder, G. Pavlenok and M. Kozlikin (eds) Social Engagement in Archaeology. Zaangażowanie społeczności lokalnych w ochronę dziedzictwa archeologicznego w Polsce, Unpublished report. Warszawa: Uniwersytet Warszawski.

Kajda, K. and Kostyrko, M. 2016 'Contemporary dimension of heritage promotion towards socially engaged archaeology', Sprawozdania Archeologiczne 68, 923. https://doi.org/10.23858/SA68.2016.001

Komisja Europejska 2017 Specjalny Eurobarometer 466. Europejczycy i dziedzictwo kulturowe.

Polska. https://ec.europa.eu/commfrontoffice/publicopinion/index.cfm/Survey/getSurvey Detail/instruments/SPECIAL/surveyKy/2150

Kostyrko, M., Kajda, K., Wroniecki, P. and Lokś, A. 2016 'Archeologia nieinwazyjna w lesie. Prospekcja wczesnośredniowiecznego grodziska w Biedrzychowicach Dolnych, woj. Lubuskie', Śląskie Sprawozdania Archeologiczne 58, 85-

99. http://doi.org/10.17427/SSA16005

Kot, M., Pavlenok, K., Jędrzejczak, H., Mieszczanek, M., Sadłowski, M., Adamski, J., Danyło, P., Skolimowski, D., Shnayder, S., Pavlenok, G. and Kolikin, M. 2015 Social Engagement in Archaeology. Zaangażowanie społeczności lokalnych w ochronę dziedzictwa archeologicznego w Polsce, Unpublished report. Warszawa: Uniwersytet Warszawski.

Kozioł, A., Trelka, M. and Florjanowicz, P. 2013 Społeczno - gospodarcze oddziaływanie dziedzictwa kulturowego. Raport z badań społecznych, Warszawa: Narodowy Instytut Dziedzictwa.

Martelli-Banégas, D., Panhard, I. and Favré, T. 2015a Image of Archaeology in Europe2015. Summary report - General public, Harris

Interactive. https://archaeologydataservice.ac.uk/archives/view/nearch 2017/downloads. $\underline{\mathrm{cfm}}$

Martelli-Banégas, D., Panhard, I. and Favré, T. 2015b Image of Archaeology in Poland2015. Study report - General public, Harris 
Interactive. https://archaeologydataservice.ac.uk/archives/view/nearch 2017/downloads. $\underline{\text { cfm }}$

Richards, J.D., Wright, H.E., Kajda, K., Marx, A., Marciniak, A., Salas-Rosenbach, K., Pawleta, M., van den Dries, M., Boom, K., Guermandi, M.P., Criado-Boado, F., Barreiro, D., Synnestvedt, A., Kotsakis, K., Kasivikis, K., Theodorudi, E., Lüth, F., Issa, M. and Frase, I. 2017 'Archaeology, heritage, and social value: public perspectives on European archaeology', European Journal of

Archaeology 21(1). https://doi.org/10.1017/eaa.2017.19

Schut, P.A.C., Scharff, D. and de Wit, L.C. 2015 'Amersfoort Agenda' in P.A.C. Schut, D. Scharff and L.C. de Wit (eds) Setting the Agenda: Giving New Meaning to the European Archaeological Heritage, EAC Occasional Paper 10, Namur: Europae Archaeologiae Consilium. 15-23. https://www.europae-archaeologiae-consilium.org/eac-occasionalpapers

Wrzosek, J. 2017 'Historyczne pole bitwy jako stanowisko archeologiczne. Wybrane problemy', Ochrona Zabytków 2(271) LXX, 79-98. 